\title{
The Influence of Organizational Culture, Compensation and Competency on Asset Misappropriation with Integrity as a Moderating Variables
}

\author{
Haryono Umar ${ }^{1}$, Rio Firnanda ${ }^{2}$, Rahima Br. Purba ${ }^{3}$ \\ ${ }^{1}$ Perbanas Institute \\ ${ }^{2}$ Universitas Trisakti \\ ${ }^{3}$ Universitas Pembangunan Panca Bud
}

\begin{abstract}
This study aims to empirically examine the relationship among variables of organizational culture, compensation, competence, with asset misappropriation and their effects in which the factor of integrity as moderating variable. The study used questionnaires to collect data from 150 respondents (samples) comprising employees of Bank DKI, BCA and Adira Finance with various levels of positions. Furthermore, the questionnaires were analyzed using SEM (structural equation modeling) and processed using the computer software SmartPLS Version 3. Based on the results of data processing, it found out that variables of organizational culture and competency did not influence asset misappropriation, while compensation and integrity negatively affected the asset misappropriation. Moreover, the factor of integrity was unable to strengthen the negative influence of organizational culture and compensation, as well as unable to weaken the positive effect of competence on asset misappropriation.
\end{abstract}

KEYWORDS: Organizational Culture, Compensation, Competence, Integrity, Assets Misappropriation

\section{INTRODUCTION}

ACFE (2018) classified fraud into two categories, namely cccupational fraud and that committed on behalf of an organization or fraudelent financial reporting. Furthermore, what is included in occupational fraud is corruption and misappropriation of assets. According to a survey conducted by ACFE in 2018, the most frequent cases of fraud were occupational fraud in the form of abuse of authority in organizations for personal gain through misuse of organizational assets or resources (ACFE, 2018).

The studies conducted in 2016 and 2017 by Certified Fraud Exeminers (CFE) revealed that out of 2,690 cases of occupational fraud, $89 \%$ were misappropriation of assets with a total loss reaching US\$114,000. Meanwhile, the incurring losses due to the cases of financial statement fraud accounted for only $10 \%$ of all, yet, the average loss value it incurred was higher, reaching US\$ 800,000. It means that cases of asset misappropriation are indeed the most frequent cases among other fraud cases, but the impact of losses is not as great as others. On the other hand, in Indonesia, the most common cases of fraud are corruption. The difference in Indonesia is thought that fraud in fraudelent financial reporting has not been widely revealed, such as information fraud crimes on the stock exchange and tax information (ACFE Indonesia, 2017).

For instance, one of the fraud cases in Indonesia was the case of 14 fictitious projects carried out by PT Waskita Karya (Persero), a well-known state-owned construction company. The fraud case was committed by 2 employees of the company by appointing subcontractors to carry out fictitious works on 14 projects. In fact, these projects have actually been performed by other companies, but they seemed to have been carried out by the appointed subcontractor. Furthermore, the employees allegedly received the transfer of funds from the subcontractor for the payment of the fictitious works. In this case, it was estimated that the state lost IDR 186 billion. In 2018, PT Waskita Karya was listed as the 'Top 5 GCG Issues in Construction Sector'. In implementation of GCG, the company required all level employees, starting from the head of the project or the head of the department or other officials who have strategic functions, to the level of the board of directors to make and report their personal assets to the Corruption Eradication Commission (KPK).

The code of ethics requires the management and employees to uphold ethical and moral values and put aside personal rather than organizational interests (Agwor and Akani, 2017). The management creates a code of conduct within the organization's internal purpose so that its members work by putting forward goals in accordance with the company's vision and mission. According to Robbins (2013), with a strong organizational culture and upholding high ethical standards, there should be a strong and positive influence on employees' behavior. Thus, good organizational culture can reduce the possibility of fraud. 


\section{International Journal of Current Science Research and Review}

ISSN: 2581-8341

Volume 04 Issue 05 May 2021

DOI: 10.47191/ijcsrr/V4-i5-04, Impact Factor: 5.825

IJCSRR@ 2021

Www.ijcsrr.org

The proverb, "power tends to be corrupt, absolute power corrupts absolutely (Gati, 2000), means that power is often misused and someone who does not have power does not have the opportunity to abuse it. Therefore, fraud cases always involve people who have power ranging from the low, middle to the highest power. Therefore, leaders must not only possess quality and competence in knowledge and skills, but they also have to possess attitude (Umar, 2016).

The fraud diamond model introduced by Wolfe and Hermanson, was further developed by Umar (2016) by inserting one more important factor, i.e. integrity. The factor is a commendable attitude and behavior possessed by an individual which makes $\mathrm{him} / \mathrm{her}$ persistent in carrying out his/her duties and obligations as the main key to build integrity is honesty (Umar, 2016).

The present research is further developed based on that of Siahaan et al. (2019) who studied the effect of the five elements of fraud star on asset misappropriation which was moderated by internal control. Likewise, it is based on the research of Pratomo et al. (2016) related to the influence of organizational culture, suitability of compensation, and competence on fraud behavior. This study added the element of integrity variable as a moderating variable which refers to Agwor and Akani's research (2017).

\section{LITERATURE REVIEW AND HYPOTHESES DEVELOPMENT}

\section{Attribution theory}

The attribution theory was introduced by Fritz Heider (1958), in which he described that a person's behavior and the process of how to determine the causes and motives for one's behavior. This theory explains what causes a person to behave in particular way towards other people or himself. This behavior can be caused by internal factors, such as traits, character, attitude, etc.; and external factors, such as the pressure of certain situations or circumstances which will influence a person's behavior. Heider (1958) also stated that internal strength (personal attributes, such as ability, effort, and fatigue) and external forces (environmental attributes, such as rules and weather) simultaneously determine human's behavior.

\section{Agency Theory}

In 1976, Jensen and Meckling introduced the agency theory which describes the relationship between shareholders as the principal and management as an agent. Management is the party employed/contracted by shareholders to work for their interests. Therefore, the management has an obligation to account for all of its work to the shareholders. On the other hand, there is another party required to supervise and inspect the activities carried out by management.

\section{Misappropriation of Assets}

According to the Association of Certified Fraud Examiners (2016), asset misappropriation is fraud or misuse of company's or other parties' property. It is a form of fraud which is the most easily detected due to its tangible nature, which is, it can be measured/calculated (defined value). Misuse/misappropriation of assets or illegal taking of assets in everyday language is called stealing (Tuanakotta, 2010). The most frequent target of looting is money because cash in the targeted bank could be directly used by the fraud perpetrators.

\section{Fraud}

Furthermore, the Association of Certified Fraud Examiners (ACFE, 2018) defined fraud as acts against the law intentionally committed for a specific purpose of personal or group gain (manipulation or misrepresentation to other parties) by people from inside or outside the organization which can directly or indirectly harm other parties. Moreover, according to Tuanakotta (2010), fraud is an act against the law which may comprise deceit, concealment or abuse of trust. These actions do not depend on the implementation of threats of violence or physical violence which can be carried out by individuals and organizations to obtain illicit benefits in the form of money, property or services, and to avoid payment or loss of services or to secure personal business profits. In addition, the Association of Certified Fraud Examiners (ACFE, 2018) also classified fraud into three categories based on the type of action, i.e. corruption, assets misappropriation (misuse/embezzlement of assets), and fraudulent statements (misrepresentation or misstatements).

\section{Fraud Star}

Deviations occur when there is an abuse of power or the authority which is executed not in accordance with the mandate as expected. The misuse is carried out for personal or group gain which leads to violations of the law. The values of virtue which should be firmly upheld have been dumped by eliminating the truth which should be carried out. In such a condition, it could be said that the fraudsters have lost their integrity values which should be upheld as well as possible (Umar, 2016). 


\section{International Journal of Current Science Research and Review}

ISSN: 2581-8341

Volume 04 Issue 05 May 2021

DOI: 10.47191/ijcsrr/V4-i5-04, Impact Factor: 5.825

IJCSRR@ 2021

www.ijcsrr.org

Based on the fraud diamond model introduced by Wolfe and Hermanson (2004) consisting of pressure, opportunity, rationalization, and capability, Umar (2016) further developed one more very important element, i.e. aspect of integrity into the existing fraud model which is later so-called the fraud star. Integrity is a personal commendable attitude and behavior which makes him or her steadfast in carrying out his/her duties and obligations in a quality manner in any conditions either without or under supervision. It means that integrity implies that someone who has understood good and bad things will strive to uphold these values even though their environment has different judgments. The fraud star theory developed by Umar (2016) can be described as follows:

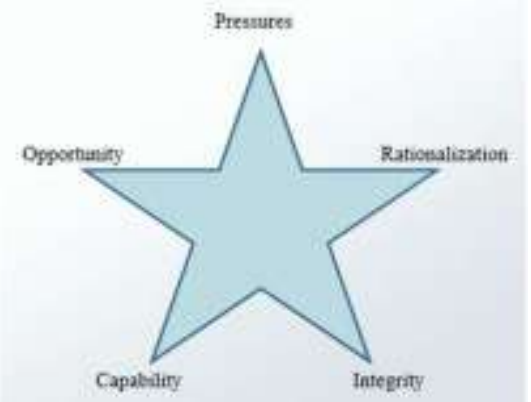

Figure 1. The elements of fraud star (Umar, 2016)

\section{Organizational culture}

According to Laura A. King, translated by Brian Marwensdy (2010), the organizational culture is defined as the values, beliefs, norms and habits which exist in an organization. Furthermore, according to Ivancevich et al. (2006), organizational culture is an important concept as a perspective for understanding individual and group behavior within an organization. Meanwhile, according to Schein (1992), it is referred to as a pattern of basic assumptions which a group has invented, discovered or developed in learning to cope with its problems of external adaptation and internal integration. Robbins (2013), also explained that organizational culture is shared perception of organization's members in it which becomes a system and a shared meaning among them. He also further explained that organizational culture tends to form high ethical standards among its members. If the organizational culture is strong and supports high ethical standards, it will have a very impactful and positive influence on worker/employee behavior.

\section{Compensation}

The idea of compensation was coined with the concept of agency theory as a branch of game theory which studied contract design to motivate rational agents (managers) to act on behalf of the principal (owner/shareholder) when there is conflict of interests between the agent and the principal. It means that the principal can limit the divergence of his/her interests by setting appropriate incentives for the agents and establishing monitoring fees designed to prevent the agent's deviant activities. In addition, some situations demand that the principal should pay the agent in order to exhibit the resources (bonding cost) to ensure that the agent will not take certain actions that would harm the principal's interests or to ensure that the principal will be compensated if the agent does not take such actions.

According to Mathis and Jackson (2011), compensation is a means for management to increase work performance, improve employees' motivation and performance. Therefore, by delivering their hard work and showing more loyalty to the company, the employees expect the company to provide an award or reward for their work performance in form of compensation.

\section{Competence}

Boyatzis (1982) defined competence as a personal basic characteristic which leads to excellent effectiveness or performance output at work. Employees who have good competence are able to see weaknesses in their organizational systems or procedures. On the other hand, Wolf and Hermanson (2004) stated that one of the traits exhibited by fraudsters is intelligence and creativity. According to Wibowo (2016), competence is the ability to carry out or perform a job or task based on skills and knowledge and is also supported by the work attitude demanded by the job. Mathis and Jeckson (2011) stated that competence is a basic characteristic related to performance achievement which consists of knowledge, skills and capability. 


\section{International Journal of Current Science Research and Review}

ISSN: 2581-8341

Volume 04 Issue 05 May 2021

DOI: 10.47191/ijcsrr/V4-i5-04, Impact Factor: 5.825

IJCSRR@ 2021

www.ijcsrr.org

\section{Integrity}

Integrity is a quality, character, or state which shows entire unity, honesty, hard work, and adequate competence (SPKN, 2017). On the other hand, Schlenker (2008) stated that integrity is a firm personal commitment to ethical ideological principles and is part of the self-concept displayed through his/her behavior. Likewise, Moroney (2008) in Fitria and Amilin (2014) stated that personal integrity is measured by the level of honesty, courage, wisdom, and responsibility. Furthermore, Schlenker (2008) in Susanto (2013) described integrity as a situation in which people are bound by what other people consider to be ethical and valuable.

Furthermore, Umar (2016) also stated that integrity is an attitude and behavior which must be performed and exemplified to anyone and anywhere because goodness will transmit positive impacts to their surroundings. Integrity provides positive inspiration and encouragement to others, and nurtures values of integrity everywhere since the problem Indonesia is now facing is lack of integrity. Regardless the elimination of system and opportunities, the relieved pressure due to the establishment of new policies, such as increment of salary and income, absence of rationalization, and transparency in the management of power, deviation will still takes place once there is a lack of integrity.

\section{Conceptual framework}

In this study, the independent variables, consisting of organizational culture, compensation and competence are used. Meanwhile, this study assigns the assets misappropriation as the only dependent variable and the element of integrity is used as a moderating variable which serves either to weaken or strengthen the influence of the independent on the dependent variable. Based on the problems statement above, a proposed conceptual framework as outlined in the research model is presented in the following figure.

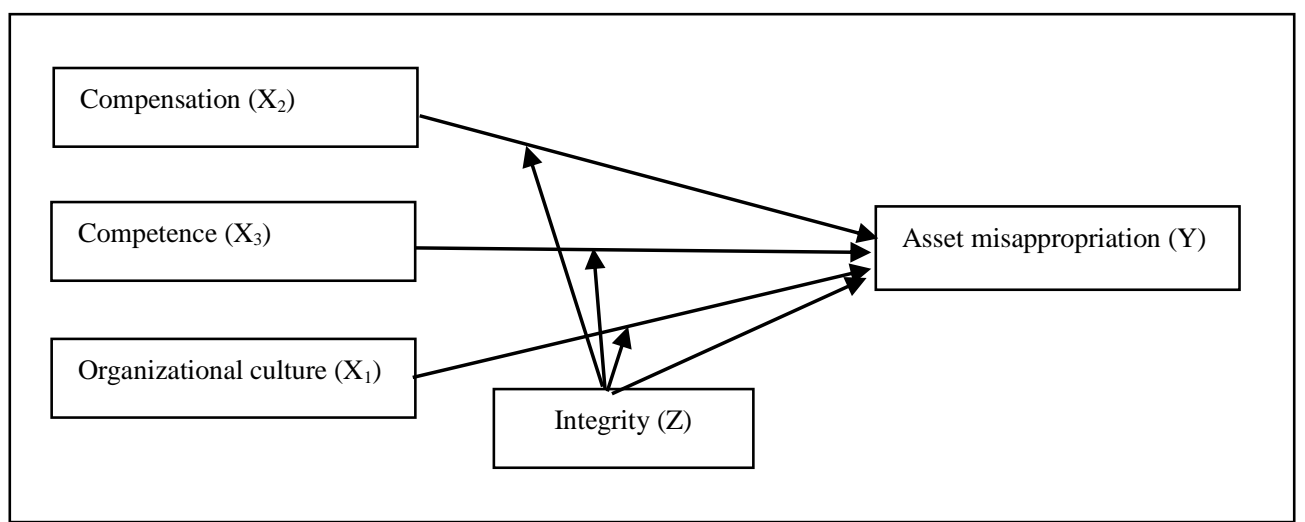

Figure 2. Conceptual framework of the research

\section{Hypotheses development}

The influence of organizational culture on asset misappropriation

Organizational culture is the values, beliefs, and norms as well as habits attributed to a certain organization (Brian Marwensdy, 2010). With a strong organizational culture and upholding high ethical standards, it is believed that the organizational culture will have a strong and positive influence on employee behavior (Roobins, 2013). Thus, positive employee's behavior can minimize the possibility of fraud and encourage organizational performance to be more effective and efficient. This is in line with research by Pratomo et al. (2016) which stated that organizational ethical culture has a negative effect on fraud.

H1: Organizational culture has a negative effect on asset misappropriation.

\section{Effect of compensation on misappropriation of assets}

Jensen and Meckling (1976) stated that providing appropriate compensation leads the agent (management) to act in accordance with what the principal expects in which the agent is expected to perform the best for the organization. If the compensation received is not appropriate, it may encourage the management to commit fraud. On the other hand, if the compensation obtained is as expected by management, it can motivate them to improve their performance. Therefore, according to some studies, such as the results of research conducted by Sulastri and Simanjuntak (2014) found that compensation had a 


\section{International Journal of Current Science Research and Review}

ISSN: 2581-8341

Volume 04 Issue 05 May 2021

DOI: 10.47191/ijcsrr/V4-i5-04, Impact Factor: 5.825

IJCSRR@ 2021

www.ijesrr.org

negative effect on fraud. Likewise, Pratomo et al. (2016) also found a negative effect of the suitability of compensation on the tendency of fraud.

$\mathrm{H} 2$ : Compensation has a negative effect on assets misappropriation.

Effect of competence on asset misappropriation

Lord Acton (1887) in Umar (2016) said that power tends to be corrupt, while absolute power corrupts absolutely. It means that power is often misused. The higher power someone holds, the greater potential he commits abuse. Therefore, many parties pay attention to one's competence in leadership. Mathis and Jeckson (2011) stated that competence is a basic characteristic related to performance achievement consisting of knowledge, skills and capability. The results of research by Pratomo et al. (2016) found a positive and significant effect of competence on fraud. The more competent a person is, the more likely the person is to commit fraud.

H3: Competence has a positive effect on misappropriation of assets.

\section{The effect of integrity on asset misappropriation}

Integrity is a commendable attitude and behavior which an individual possesses which makes him persistent in carrying out his duties and obligations in a quality manner either under or without supervision circumstances. A person who has integrity will not be easily caught in seduction and pressure from any party because of his moral and ethical constancy (Umar, 2016). Research conducted by Agwor and Akani (2017) found a negative and significant relationship between integrity and assets misappropriation. Likewise, Bakri et al (2017) also found a negative and significant effect of integrity on asset misappropriation. H4: Integrity has a negative effect on the misappropriation of assets.

The influence of organizational culture moderated by integrity on asset misappropriation

Organizational culture is an implicit perception and convention which is carried out and accepted by organization's members as a subject of obedience. It contains principles of moral values and norms of a group or organization. If fraudulent behavior in an organization is normal and common, it means that every member of the organization will tend to commit fraud continuously. This is due to the rationalization/justification of fraud committed (Siregar and Hamdani, 2018). Research conducted by Siregar and Hamdani (2016) found that organizational culture has a negative and significant effect on fraud.

H5: Integrity strengthens the negative influence of organizational culture on asset misappropriation.

The effect of compensation moderated by integrity on assets misappropriation

Compensation is a reward, provided by the organization to members who have carried out their duties and functions in achieving organizational goals. Pratomo et al. (2016) stated that appropriate compensation has a negative effect on fraud. Therefore, the more appropriate the compensation employees receive, the less likely the fraud will be to occur. Since individuals perceive their needs are sufficiently fulfilled, they avoid wrongdoings. Bakri et al (2017) stated the negative effect of integrity on asset misappropriation.

H6: Integrity strengthens the negative effect of compensation on misappropriation of assets.

The effect of competence moderated by integrity on asset misappropriation

The more competent a person is, the higher the tendency he might commit fraud. It is because a competent person can carry out his duties well and understand the downsides/drawbacks of the control system. The results of research conducted by Pratomo et al. (2016) showed that the competence has a positive effect on the tendency of fraud. Well competent employees are expected and beneficial for the company. However, with the person's high competence and power, fraud is more likely to occur. H7: Integrity reduces the positive influence of competence on misappropriation of assets.

\section{RESEARCH METHODS}

\section{Research design}

The present study is classified as a type of causal research using a quantitative approach of an explanative survey method. This quantitative research was conducted by testing the hypothesis. Based on the explanation level, this research is classified as a causal associative study with the aim of determining a causal relationship, i.e. the effect of the independent variable (X) on the dependent variable (Y) (Sugiyono, 2017). In this study, the dependent variable is fraud, while the dependent variables are 


\section{International Journal of Current Science Research and Review}

ISSN: 2581-8341

Volume 04 Issue 05 May 2021

DOI: 10.47191/ijesrr/V4-i5-04, Impact Factor: 5.825

IJCSRR@ 2021

Www.ijcsrr.org

organizational culture, compensation, and competence using integrity as the moderating variable ( $Z$ ). This study used crosssectional studies data, i.e. research using the same period of time while the questionnaires were distributed to the respondents to obtain information.

\section{Measurement of research variables and indicators}

In this study, gathering data from respondents was performed by distributing questionnaires to the respondents. They were asked to answer several options using the ordinal scale, i.e. the Likert scale, which shows how strong the level of agreement or disagreement toward an asked statement. The scale is very user friendly, easily understood by the respondents, and visually also more attractive and easy to fill. It consists of 5 categories of answers, namely strongly disagree with a value of 1 , the second is disagree with a value of 2 , third option is somewhat agree with a value of 3 , then the fourth is agree with a value of 4 , and the last one is fifth, which represents strongly agree with a value of 5 . The following are the indicators used in this research

Table 1. Research variables and indicators

\begin{tabular}{|c|c|c|}
\hline No & Variables & Indicators \\
\hline 1 & $\begin{array}{l}\text { Organizational culture - } \\
\text { Robbins (2013), Siregar dan } \\
\text { Hamdani (2018) }\end{array}$ & $\begin{array}{l}\text { 1. A visible role model } \\
\text { 2. Communication of ethical expectations } \\
\text { 3. Ethical training } \\
\text { 4. Punishment for ethical action } \\
\text { 5. Ethical protection mechanisms }\end{array}$ \\
\hline 2 & $\begin{array}{l}\text { Compensation - Gibson et. } \\
\text { all (2012), Colquitt (2001), } \\
\text { dan Siregar dan Hamdani } \\
(2018)\end{array}$ & $\begin{array}{l}\text { 1. Financial compensation } \\
\text { 2. Appreciation for successful work } \\
\text { 3. Promotion } \\
\text { 4. Work facilities } \\
\text { 5. Compensation according to views and feelings }\end{array}$ \\
\hline 3 & $\begin{array}{l}\text { Competence - Siregar } \\
\text { (2018) \& Pratomo (2016)- } \\
\text { Pratomo (2016) Wolfe \& } \\
\text { Hermanson } \\
(2004)\end{array}$ & $\begin{array}{l}\text { 1. Competence to serve } \\
\text { 2. Competence to lead } \\
\text { 3. Competence to think } \\
\text { 4. Position/function } \\
\text { 5. Confidence/ego } \\
\text { 6. Immunity to stress }\end{array}$ \\
\hline 4 & $\begin{array}{l}\text { Integrity - Bakri et al. } \\
(2017) \& \text { Siahaan (2019) }\end{array}$ & $\begin{array}{l}\text { 1. Honesty } \\
\text { 2. Trustworthiness } \\
\text { 3. Firmness } \\
\text { 4. Consistency } \\
\text { 5. Punishment } \\
\text { 6. Rewards }\end{array}$ \\
\hline 5 & $\begin{array}{l}\text { Asset misappropriation - } \\
\text { ACFE (2018) \& Siahaan } \\
(2019)\end{array}$ & $\begin{array}{l}\text { Cash misappropriation: } \\
\text { 1. Recording fictitious expenses } \\
\text { 2. Budget revision } \\
\text { 3. Illegal expenditure } \\
\text { Non-cash misappropriation: } \\
\text { 3. Manipulation of organizational wealth management } \\
\text { 4. Engineered auctions } \\
\text { 5. Change asset status } \\
\text { 6. Manipulate the procurement of goods } \\
\text { 7. Picking up goods at the warehouse / office }\end{array}$ \\
\hline
\end{tabular}




\section{International Journal of Current Science Research and Review}

ISSN: 2581-8341

Volume 04 Issue 05 May 2021

DOI: 10.47191/ijesrr/V4-i5-04, Impact Factor: 5.825

IJCSRR@ 2021

www.ijcsrr.org

\section{Method of data collection}

The primary data were obtained from field research carried out by conducting a direct observation on the agency as the object of the study and through distributing questionnaires. In this study, the population, the total of which accounted for 47,785 people was the employees who worked as sales operation/front liner division at three companies, i.e. PT Bank Central Asia, PT Bank DKI, and PT Adira Dinamika Multifinance. The reason why the division was chosen because it was the responsible party for the companies' assets management. This study used a sample size according to the theory proposed by Sekaran (2016) that a sample size between 30 and 500 is suitable for most studies in multivariate research. The sample size should be several times (preferably 5 times or more) larger than the number of indicators in the study. In this study, the researchers used 5 (five) times the indicators (30 indicators in the questionnaire). The five variables were three exogenous latent variables, one endogenous latent variable, and one exogenous latent variable as moderating variables. Therefore, the minimum total sample used in this study was 150 samples taken from the minimum multiplication of the sample, i.e. 5 (five) times 30 indicators. Meanwhile, the sampling method of non-probability through purposive sampling was used and the data collection was carried out by means of distributing questionnaires (hardcopy) and through online media. For online form, the questionnaires were created on the google site or google form supplied with respective link which could be easily distributed via e-mail or social media applications, such as Line, Whatsapp, and so on.

\section{Method of data analysis}

The data were analyzed using Partial Least Square (PLS) version 3.2.1, a component or variant-based Structural Equation Modeling (SEM) equation model (Ghozali, 2015). PLS uses a three-stage iteration process, each of which produces an estimate for analysis, namely the first stage with outer model analysis (convergence validity with loading factor, AVE communality $>0.5$; and discriminant with cross loading $>0.5$; and reliability with Cronbach alpha $>0.6$, composite reliability $>0.7$ ). Furthermore, at the second stage, it generates the inner model (variance of the endogenous construct of the R-square value, predictive relevance Qsquare, overall fit index (GoF), bootstrapping method), and finally the third stage was testing hypotheses (direct effect and moderating effect with sample mean showing both positive and negative directions which must be in line with the hypotheses, probability-value $<0.05$, T-statistics $>1.64$ which is one tailed.

\section{DISCUSSIONS}

\section{Description of research objects}

The population in this study were employees of PT Bank Central Asia, PT Bank DKI, and PT Adira Dinamika Multifinance who worked in the sales operation/front liner division. Totally, it accounted for 47,785 employees (Bank DKI: 3,451 employees; BCA: 24,941 employees; and Adira: 19,393 employees). The questionnaires were distributed through google form, email, or questionnaire sheets to the respondents. The purposive sampling method was used with sampling limit of 150 respondents. The following table presents the distribution data of the research samples.

Table 2. Distribution data of the research samples

\begin{tabular}{|l|l|l|}
\hline No. & Object of the study & No. of respondents \\
\hline 1 & PT Bank DKI & 56 \\
\hline 2 & PT Bank Central Asia Tbk. & 64 \\
\hline 3 & PT Adira Dinamika Multifinance & 30 \\
\hline & Total & 150 \\
\hline
\end{tabular}

\section{Descriptive statistics}

Descriptive statistics are descriptions of respondents' answers which aim to describe data as seen from the mean, standard deviation presented in the table for each exogenous, moderating, and endogenous variable. In this study, the mean is the average value of all respondents' answers through the research variables, while the standard deviation is a variation of the respondent's answers, namely the number 1 which means strongly disagree up to 5 which means strongly agree. 


\section{International Journal of Current Science Research and Review}

ISSN: 2581-8341

Volume 04 Issue 05 May 2021

DOI: 10.47191/ijesrr/V4-i5-04, Impact Factor: 5.825

IJCSRR@ 2021

www.ijcsrr.org

Table 3. Descriptive statistics

\begin{tabular}{|l|l|l|l|l|l|}
\hline Variables & $\mathbf{N}$ & Minimum & Maximum & Mean & Std. deviation \\
\hline Organizational culture & 150 & 1 & 5 & 4.101 & 0.787 \\
\hline Compensation & 150 & 1 & 5 & 4.112 & 0.701 \\
\hline Competence & 150 & 1 & 5 & 4.041 & 0.721 \\
\hline Integrity & 150 & 1 & 5 & 4.461 & 0.668 \\
\hline Asset misappropriation & 150 & 1 & 5 & 1.507 & 0.724 \\
\hline
\end{tabular}

\section{ANALYSIS OF RESEARCH RESULTS}

\section{Measurement model (outer model)}

In analysis of the measurement model (outer model), Hair et al. (2017) suggested that it should be carried out through a path weighting scheme, a maximum iteration value of 300 and the value of stop criterion at 7 , where the convergent validity results in outer loading, while AVE and communality are greater than 0.5 , which is considered valid.

The Fornell-Lacker criterion for discriminant validity is that the latent construct as a whole has a discriminant validity value because it has the square root of the AVE which is greater than correlation value with other latent constructs, as shown in the table below.

Table 4. Latent Variables and correlation value

\begin{tabular}{|l|l|l|l|l|l|}
\hline Latent variables & BO & IG & KMT & KSI & PA \\
\hline Organizational culture & 0.791 & & & & \\
\hline Compensation & 0.466 & 0.850 & & & \\
\hline Competence & 0.644 & 0.492 & 0.808 & & \\
\hline Integrity & 0.721 & 0.406 & 0.800 & 0.823 & \\
\hline Asset misappropriation & -0.466 & -0.513 & -0.545 & -0.587 & 0.892 \\
\hline
\end{tabular}

In conclusion, the results of the discriminant validity test through the Fornell-Lacker criterion for the latent construct as a whole have discriminant validity values

Table 5. Latent variables

\begin{tabular}{|l|l|l|l|}
\hline Latent variables & $\begin{array}{l}\text { Composite } \\
\text { reliability }\end{array}$ & Cronbach's Alpha & Remark \\
\hline Organizational culture & $0.893 \geq 0.70$ & $0.856 \geq 0.70$ & Reliable \\
\hline Compensation & $0.911 \geq 0.70$ & $0.864 \geq 0.70$ & Reliable \\
\hline Competence & $0.918 \geq 0.70$ & $0.893 \geq 0.70$ & Reliable \\
\hline Integrity & $0.913 \geq 0.70$ & $0.882 \geq 0.70$ & Reliable \\
\hline Asset misappropriation & $0.969 \geq 0.70$ & $0.963 \geq 0.70$ & Reliable \\
\hline
\end{tabular}

The results of the internal consistency reliability values in the table above indicate that the five latent constructs, namely organizational culture, compensation, competence, integrity, and asset misappropriation have a composite reliability value of $0.893 ; 0.911 ; 0.918 ; 0.913$; and 0.969 (the five construct variables $\geq 0.7$ ) and the Cronbach's alpha value of 0.856 ; $0.864 ; 0.893$; 0.882 ; and 0.963 (five construct variables $\geq 0.6$ ). It can be concluded that all of the five latent constructs are claimed to be reliable; thus, they can proceed for analysis to the next stage, namely structural model analysis.

\section{Structural model analysis (inner model)}

To determine the predictive strength of the structural model, the adjusted R2 value of each endogenous construct can be used (Ghozali, 2015). 


\section{International Journal of Current Science Research and Review}

ISSN: 2581-8341

Volume 04 Issue 05 May 2021

DOI: 10.47191/ijesrr/V4-i5-04, Impact Factor: 5.825

IJCSRR@ 2021

www.ijesrr.org

Table 6. Endogenous variable

\begin{tabular}{|l|l|l|}
\hline Endogenous variable & Adjusted R square & Remark \\
\hline Asset misappropriation & 0.449 & Weak \\
\hline
\end{tabular}

It can be seen that the value of adjusted R2 is $44.9 \%$ in the endogenous construct of asset misappropriation. It indicates that the four exogenous construct variables, namely organizational culture, compensation, competence, and integrity weakly explains the variance of the endogenous construct of asset misappropriation only by $44.9 \%$. The criteria of overall fit index evaluation for the entire model obtained from the average communalities index is multiplied by the R2 model.

Tabel 7. Latent constructs

\begin{tabular}{|l|l|l|}
\hline Latent construct & AVE & R2 \\
\hline Organizational culture & 0.796 & 0.449 \\
\hline Compensation & 0.722 & - \\
\hline Competence & 0.626 & - \\
\hline Integrity & 0.678 & - \\
\hline Asset misappropriation & 0.652 & - \\
\hline Average & 0.695 & 0.449 \\
\hline GOF value & $\mathbf{0 . 5 5 9}$ & \\
\hline Remarks & Great value of GOF \\
\hline
\end{tabular}

From the table above, it can be observed that the overall fitness of the model shows a value of 55.9\%. It shows that the model obtained in this study as a whole has a great predictive power in explaining the relationship of exogenous constructs. Based on the description of the goodness of fit inner model criteria, the suitability of the model as a whole, the structurally formed model generates the following formula:

\section{$\mathrm{PA}=\alpha-0.011 \mathrm{BO}-0.328 \mathrm{KSI}-0.084 \mathrm{KMT}-0.310 \mathrm{IG}-0.34 \mathrm{BO}{ }^{\star} \mathrm{IG}+$ $0.236 \mathrm{KSI}^{*} \mathrm{IG}+0.096 \mathrm{KMT}^{*} \mathrm{IG}$}

\section{Result of direct effect test}

Based on the hypotheses development and the provisions of the rule of thumb for accepting the hypothesis, the results of the direct effect test must take the parameter output derived from the total effect table instead of the path coefficients table. It is because there is an exogenous construct in the research model, namely the latent construct of internal control as a moderator. The following table presents the results of the total effect from the direct effect test.

Table 8. Direct effect

\begin{tabular}{|c|c|c|c|c|c|c|}
\hline \multirow[b]{2}{*}{ Hypothesis } & \multirow[b]{2}{*}{ Correlation } & \multirow[b]{2}{*}{ Exception } & \multicolumn{3}{|c|}{ Direct effect } & \multirow[b]{2}{*}{ Conclusions } \\
\hline & & & $\begin{array}{l}\text { Sample } \\
\text { mean }\end{array}$ & t-statistic & P-value & \\
\hline H1 & $\mathrm{BO} \rightarrow \mathrm{PA}$ & $(-)$ & -0.111 & 0.111 & 0.912 & H1 rejected \\
\hline $\mathrm{H} 2$ & $\mathrm{KSI} \rightarrow \mathrm{PA}$ & $(-)$ & -2.597 & 2.597 & 0.010 & H2 accepted \\
\hline $\mathrm{H} 3$ & $\mathrm{KMT} \rightarrow \mathrm{PA}$ & $(+)$ & -0.722 & 0.722 & 0.471 & H3 rejected \\
\hline $\mathrm{H} 4$ & $\mathrm{IG} \rightarrow \mathrm{PA}$ & $(-)$ & -3.310 & 3.506 & 0.000 & H4 accepted \\
\hline
\end{tabular}

The analysis on moderating effect is carried out for the moderating variable of integrity in the form of latent metrics. It was performed using an analysis on the interaction effect between exogenous and moderating variables in influencing endogenous variables, i.e. moderating variables with the type of reflective indicator through the product indicator approach. The following table presents the results of the total effect from the direct effect test. 


\section{International Journal of Current Science Research and Review}

ISSN: 2581-8341

Volume 04 Issue 05 May 2021

DOI: 10.47191/ijesrr/V4-i5-04, Impact Factor: 5.825

IJCSRR@ 2021

WWw.ijcsrr.org

Table 9. Total effect from direct effect test

\begin{tabular}{|c|c|c|c|c|c|c|}
\hline \multirow[b]{2}{*}{ Hypothesis } & \multirow[b]{2}{*}{ Correlation } & \multirow[b]{2}{*}{ Exception } & \multicolumn{3}{|c|}{ Direct effect } & \multirow[b]{2}{*}{ Conclusion } \\
\hline & & & $\begin{array}{l}\text { Sample } \\
\text { mean }\end{array}$ & t-statistic & P-value & \\
\hline H5 & $\mathrm{BO} * \mathrm{IG} \rightarrow \mathrm{PA}$ & $(-)$ & -0.340 & 2.410 & 0.016 & H5 rejected \\
\hline H6 & KSI*IG $\rightarrow$ PA & $(-)$ & -0.236 & 1.684 & 0.093 & H6 rejected \\
\hline H7 & $\mathrm{KMT}^{*} \mathrm{IG} \rightarrow \mathrm{PA}$ & $(+)$ & -0.096 & 0.713 & 0.476 & H7 rejected \\
\hline
\end{tabular}

Research results and discussions

The effect of organizational culture on asset misappropriation

Based on the results of this study, organizational culture has no effect on asset misappropriation. It is also revealed from this study that the implementation of organizational culture is merely for the sake of obligations. The respondents did not yet realize the importance of implementing a good culture in the organization. However, the results of this study are not in line with that conducted by Pratomo et al. (2016) which found a negative and significant influence of organizational culture on the occurrence of fraud.

\section{The effect of compensation on assets misappropriation}

Compensation has a negative and significant impact on the assets misappropriation. The results of this study indicate that when the compensation is received as expected, the occurrence of assets misappropriation is reduced. Employees do not feel as burden with high workload if they earn benefits from what they do. Furthermore, this study is in line with the research conducted by Pratomo et al. (2016) which found a negative and significant effect of compensation received on fraud behavior.

\section{The effect of competence on asset misappropriation}

Competence has no effect on assets misappropriation. Based on the e result of this study, it indicates that competence does not encourage an individual nor lead his desire to commit asset misappropriation. Individuals who have authority over assets do not necessarily have the desire to commit fraud. However, this research is not in line with the research results of Pratomo et al. (2016) which revealed that competence has positive effect on the occurrence of fraud.

\section{The effect of integrity on asset misappropriation}

Integrity has a negative and significant effect on asset misappropriation. The study results indicate that individuals who uphold the value of integrity can hinder their intention once they have the desire to commit asset misappropriation. Agwor and Akani (2017) also found that integrity has negative and significant effect on asset misappropriation.

\section{The effect of integrity in moderating organizational culture on asset misappropriation}

Integrity is not able to strengthen the negative influence of organizational culture on asset misappropriation. Based on the study result, it indicates that integrity is not able to make individuals obey the rules and code of ethics existing in an organization; thus, it can allow the asset misappropriation. In fact, it is integrity as a commendable behavior for individuals to be firm in performing their duties. Nevertheless, this study results are not in line with the research conducted by Agwor and Akani (2017) which found that integrity reduced the influence of the factors of the fraud triangle on asset misappropriation.

\section{Effect of Integrity in moderating compensation on assets misappropriation}

In this study, it is found that integrity is not able to strengthen the effect of compensation on assets misappropriation. It means that the individual only cares about the compensation he receives and will not care about integrity when facing with gift. However, the results of this study are inconsistent with those conducted by Agwor and Akani (2017) who found that integrity weakened the influence of the factors in the fraud triangle.

\section{The effect of integrity in moderating competence on asset misappropriation}

Based on these study results, it is found that integrity is unable to weaken the effect of competence on asset misappropriation. It indicates that competent individuals who commit asset misappropriation ignore the values of honesty. 


\section{International Journal of Current Science Research and Review}

ISSN: 2581-8341

Volume 04 Issue 05 May 2021

DOI: 10.47191/ijcsrr/V4-i5-04, Impact Factor: 5.825

IJCSRR@ 2021

WWw.ijcsrr.org

Nonetheless, the results of this study are not in line with those which were conducted by Agwor and Akani (2017) who found that integrity was able to weaken the positive effect of ability to the asset misappropriation.

\section{CONCLUSIONS}

1. Organizational culture has no effect on asset misappropriation. However, the results of this study are not in line with that of Pratomo et al. (2016) who found a negative and significant influence of organizational culture on the occurrence of fraud.

2. Compensation has a negative and significant impact on asset misappropriation. Furthermore, this study is in line with that conducted by Pratomo et al. (2016) which found a negative and significant effect on the tendency of fraud behavior.

3. Competence has no effect on asset misappropriation. Moreover, this research result is in line with that of Siregar and Hamdani's (2018) which found that competence did not have a significant effect on fraud.

4. Integrity has a negative and significant effect on the misappropriation of assets. This study is in line with the research which was conducted by Siahaan et al. (2019) who found a adverse effect of integrity on asset misappropriation. According to their findings, integrity will not make an individual forced or trapped into committing deviant acts.

5. Integrity is unable to strengthen the negative effect of organizational culture on asset misappropriation. The results of this study indicate that integrity cannot make individuals obey the rules and code of ethics made by the organization so as to avoid asset misappropriation. Integrity is a commendable individual attribute to be firm in performing their duties.

6. Integrity is not able to reduce the effect of compensation on the misappropriation of assets. It indicates that the individuals only care about the compensation they receive and will not take into account the integrity when they encounter something related to gift (gratification). There are several indicators of the invalid integrity variable, one of which is about the gift from the party who committs the fraud.

7. In this study, it is revealed that integrity is unable to reduce the influence of competence on misappropriation of assets. It means that competent individuals who commit misappropriation of assets ignore the values of honesty. Another factor which encourages the individual to commit fraud is stronger than the individual's competence.

\section{REFERENCES}

1. ACFE Indonesia. 2017. Survei Fraud Indonesia 2016. Jakarta. ACFE Indonesia Chapter.

2. ACFE. 2018. Report to Nations. Association of Certified Fraud Examiners. Austin.

3. Agwor, ThankGod dan Akani, Fyneface N. 2017. Internal Control System and Fraud Prevention in Public Serivce of Bayelsa State. International Journal of Novel Research in Marketing Management and Economics, Vol. 4.

4. Bakri, Mustafa H.H., Mohamed, Norazida., Said, Jamaliah. 2017. Mitigating Asset Misappropriation Through Integrity and Fraud Risk Elements. Journal of Financial Crime, Vol. 24 No. 2, pp. 242-255, doi: 10.1108/JFC-04-2016-0024.

5. Boyatzis, Richard E., dan Dubuc, Paul. 1982. The Competent Manager: A Model for Effective Performance.

6. Fawaid, J., Akbar, B., Effendy, K., \& Lukman, S. (2020). The Influence of Organizational Climate, Coordination and Organizational Commitment to Collective Leadership in Collegial Community Consultants of the People of the Republic of Indonesia. Journal of Public Administration and Governance, 10(3), 344354-344354.

7. Ghozali, Imam. 2016. Aplikasi Analisis Multivariete Dengan Program IBM SPSS 23 (Edisi 8). Cetakan ke VIII. Semarang : Badan Penerbit Universitas Diponegoro.

8. Hair, Joseph E, Jr et all. 2017. A Primer on Partial Least Square Structural Equation Modeling (PLS-SEM). SAGE Publication, Inc. California. USA.

9. Heider, Fritz. 1958. ThePpsychology of Interpersonal Relations, New York: Wiley.

10. Hermanson, Dana R., Justice, Scot E., Ramamoorti, Sridhar., dan Riley, Richard A. Unique Charasteristic of Predator Fraud. Journal of Forensic Accounting Research, Vol. 2, No. 1, pp A31-A48.

11. Jensen, Michael C., dan Meckling, William H. 1976. "Theory of The Firm: Managerial Behavior, Agency Cost, and Ownership Structure", Journal of Financial Economics, Vol. 3, No. 4.

12. L. Mathis, Robert \& H. Jackson, John. 2011. Human Resource Management (edisi 10). Jakarta: Salemba Empat.

13. Pratomo, A., Pramuka, B. A., dan Maghfiroh, S. 2016. Analisis Fraud Diamond Terhadap Kecenderungan Perilaku Fraud pada Pengelola Keuangan Pemerintah. Simposium Nasional Akuntansi XIX. Lampung. 


\section{International Journal of Current Science Research and Review}

ISSN: 2581-8341

Volume 04 Issue 05 May 2021

DOI: 10.47191/ijesrr/V4-i5-04, Impact Factor: 5.825

IJCSRR@ 2021

WWw.ijcsrr.org

14. Scott, William R. 2015. Financial Accounting Theory, 7th Edition, Canada Inc. Prentices Hall.

15. Sekaran, U., \& Bougie, R. 2016. Research Methods for Business: A Skill Building Approach, 7th Edition. Chichester, United Kingdom: Wiley.

16. Siahaan, Magda., Umar, Haryono., Purba, Rahima Br. 2019. Fraud Star Drives to Asset Misappropriation Moderate by Internal Controls. Journal of Southwest Jiatong University, Vol. 54 No. 4.

17. Sekaran, Uma dan Bougie, R. 2017. Metode Penelitian untuk Bisnis Pendekatan Pengembangan-Keahlian. Jakarta. Salemba Empat

18. Sugiyono. 2017. Metode Penelitian Kuantitatif Kualitatif dan R\&D. Jakarta: Penerbit Alfabeta

19. Tuanakotta, T, M. 2010. Akuntansi Forensik dan Audit Investigatif. Jakarta: Salemba Empat.

20. Umar, Haryono dan Rahima Br. Purba. 2019. Audit Forensik Lawan Korupsi. Jakarta : Universitas Trisakti.

21. Umar, Haryono. 2016. Corruption the Devil, Jakarta: Penerbit Universitas Trisakti.

22. Umar, H., \& Purba, R. B. (2018). Management Determinants Among The Relation of Corruption, Accountability, And Performance. Int. J. Civ. Eng. Technol, 9(9), 768-773.

23. Undang-Undang Nomor 31 tahun 1999 j.o Undang Undang Nomor 20 Tahun 2001, Tindak Pidana Korupsi

24. Wolfe, D. T dan Dana, R. Hermanson. 2004. The Fraud Diamond: Considering the Four Elements of Fraud.

Cite this Article: Haryono Uma, Rio Firnanda, Rahima Br. Purba (2021). The Influence of Organizational Culture, Compensation and Competency on Asset Misappropriation with Integrity as a Moderating Variables. International Journal of Current Science Research and Review, 4(5), 346-357 